\title{
KAJIAN PENERAPAN KONSEP TDR SKEMA KOMPENSASI NON FINANSIAL PADA KAWASAN KUMUH DI KELURAHAN SEKAYU
}

\section{IMPLEMENTATION STUDY OF TDR NON-FINANCIAL COMPENSATION SCHEME IN SLUM AREA IN KELURAHAN SEKAYU}

\section{Bosman Pangaribuan' Ragil Haryanto ${ }^{2}$}

'Kementerian Pekerjaan Umum dan Perumahan Rakyat; Jalan Pattimura No. 20 Jakarta Selatan; bosman.boni123@gmail.com 2Departemen Perencanaan Wilayah dan Kota; Universitas Diponegoro, Semarang, Jawa Tengah; ragil.haryanto@pwk.undip.ac.id Info Artikel:

\section{ABSTRAK}

Penanganan kawasan permukiman kumuh khususnya "kampung kota" harusnya tidak lagi dilakukan dengan cara konvensional. Gentrifikasi sering kali terjadi di kampung kota karena keterbatasan lahan di perkotaan. Konsolidasi tanah vertikal yang merupakan salah satu perangkat Transferable Development Right dengan skema Kompensasi non finansial diharapkan dapat menjadi solusi dalam penanganan kawasan kumuh di perkotaan. Selain dapat membantu pemerintah karena keterbatasan anggaran juga dapat membantu mencapai perencanaan penataan kota yang lebih baik, tertata dan terarah. Kampung Sekayu adalah salah satu kampung Kota yang berada di kota Semarang yang merupakan permukiman kumuh yang sedang mengalami gentrifikasi dan semakin terjepit dengan pembangunan di sekitarnya. Penelitian ini bertujuan untuk mengkaji apakah konsep TDR dengan skema kompensasi non finansial dengan pelaksanaan dalam bentuk konsolidasi tanah vertikal dapat menjadi solusi dalam penanganan kumuh dan untuk mencegah terjadinya gentrifikasi di kawasan tersebut. Metode penelitian ini menggunakan kualitatif deskriptif dengan melakukan observasi lapangan, wawancara mendalam serta kajian literature dan data sekunder sebagai pelengkap untuk menggali sebanyak mungkin informasi dilapangan dan melihat kenyataan dilapangan. Secara umum, konsep konsolidasi tanah vertikal ini mendapat respon yang bagus dari stakeholder yang ada di kota Semarang namun terkait kompensasi non finansial yang umumnya diberikan dalam bentuk bonus zonasi dengan kelebihan lantai bangunan menjadi terkendala karena pengaturan izin zonasi di Kota Semarang dengan ketinggian diatas 5 lantai merupakan kewenangan Dinas perhubungan dalam kaitannya dengan kawasan keselamatan operasi penerbangan (KKOP) bandara Ahmad Yani Kota Semarang. Satu-satunya bentuk kompensasi non finansial yang paling memungk inkan adalah kemudahan perijinan dari pemerintah kota Semarang.

Kata Kunci : Penanganan kawasan kumuh; Gentrifikasi; TDR KOmpensasi Non Finansial; Konsolidasi Tanah Vertikal; Kampung Sekayu

\section{ABSTRACT}

Handling of slum areas, especially "Kampung Kota", should no longer be carried out by conventional means. Gentrification in kampung kota often occurs because of limited land in urban areas. Vertikal land consolidation which as one of Transferable Development Right with a non-financial compensation scheme expected as the solution on slums handled in urban areas. Apart from being able to help the government because of budget constraints, it can also help achieve better, organized and directed urban planning. Kampung Sekayu, as one of kampung kota in Semarang, which as a slum area that experienced gentrification and increasingly caught up in the development around it. This study aims to examine whether the concept of Transferable Development Rights with non-financial compensation schemes with implementation vertikal land consolidation form, it can be a solution in slums handled and prevent the occurrence of gentrification in the area. This research method uses descriptive qualitative by field observations, in-depth interviews and, literature review, and secondary data as a complement to exploring information as much as possible and saw the reality in the field. Generally, a concept of vertikal land consolidation received a good response from stakeholders in Semarang City but related to non-financial compensation which generally given the form of zonation bonuses with excess building floors being constrained. it because of zoning permit arrangements in Semarang City which above 5 floors on the authority of Transportation Agency in relation to flight operation safety area 
Pangaribuan, Haryanto/ Jurnal Pembangunan Wilayah dan Kota, Vol.15, No.2, 2019, 108-121

Doi: https://doi.org/10.14710/pwk.v15i2.21435

(KKOP) of Ahmad Yani Airport in Semarang City. Non-financial compensation scheme that most beneficial to ease of licensed from Semarang city government.

Keywords: Handling of slum area; Gentrification; Non-financial compensation Transferable Development Rights (TDR); Vertikal Land Consolidation; Kampung Sekayu

Copyright $\odot 2019$ GJGP-UNDIP

This open access article is distributed under $a$ Creative Commons Attribution (CC-BY-NC-SA) 4.0 International license.

\section{PENDAHULUAN}

Penanganan kawasan permukiman kumuh masih menyisakan permasalahan tersendiri dengan target o \% seperti diamanatkan dalam RPJM 2015-2019. Penanganan kawasan kumuh di perkotaan harusnya mendapat prioritas utama dengan metode yang berbeda dari yang biasanya dengan sekedar memberikan layanan dasar infrastruktur dasar (Seong-kyu, 2008). Kampung kota yang identik dengan kawasan kumuh seharusnya mendapat perhatian dari pemerintah kota agar tidak hilang begitu saja dengan terjadinya gentrifikasi. Kampung kota yang umumnya semakin terjepit dengan kondisi pembangunan gedung-gedung tinggi menjadikannya sebagai "kampung terjepit" dan butuh penyelamatan. Gentrifikasi bagi pemerintah kota pada dasarnya bersifat positif dengan berjalannya pembangunan secara alami dan berdasarkan kebutuhan pasar, namun di sisi lain hal tersebut akan berdampak negatif bagi kondisi sosial budaya masyarakat yang cenderung akan hilang dari kawasan tersebut.

Perkembangan kota Semarang saat ini semakin pesat, hal ini ditandai semakin banyaknya pembangunan gedung-gedung tinggi seperti hotel, apartement dan pusat perbelanjaan. Kebutuhan lahan untuk pembangunan semakin memakan lahan masyarakat yang ada di pusat kota, termasuk kawasankawasan yang kumuh dan kampung kota. Kondisi ini juga menyebabkan terjadinya gentrifikasi yang sulit dibendung tanpa adanya suatu kebijakan baru terkait upaya pengembangan kota yang dilakukan oleh para pengembang. Beberapa kasus gentrifikasi di Kota Semarang yang tercatat dalam beberapa penelitian adalah; Kampung Mijen, Kampung Basahan, Kampung Morojayan, Kampung Petroos, dan Kampung Jayenggaten yang semuanya berada di Kecamatan Semarang Tengah (Wilonoyudho, 2014). Permukiman kumuh yang ada di perkotaan dan kampung kota pada dasarnya sangat berpotensi sebagai land banking dalam upaya pengembangan kota. Pemanfaatan kawasan kumuh atau kampung kota sebagai land banking untuk pengembangan perkotaan sekaligus dalam upaya penyelamatan lahan-lahan di pinggir kota dan lahan pertanian sebaiknya dapat dilakukan dengan upaya-upaya yang terbaik sehingga dapat mencegah terjadinya gentrifikasi lebih lanjut. Pemanfaatan lahan di kawasan permukiman kumuh pusat kota juga sebaiknya dapat di sesuaikan dengan aturan terkait zonasi.

Kota Semarang termasuk salah satu kota di Indonesia yang memiliki kampung kota yang cukup banyak dan masing-masing kampung kota tersebut memiliki nilai sejarah sendiri yang nilai sosial budaya yang terdapat di dalamnya perlu di perhatikan untuk dapat di pertahankan. Kampung kota umumnya identik juga dengan kekumuhan dan kemiskinan yang terdapat di dalam kawasan tersebut. Kampung Sekayu yang terdapat di Kelurahan Sekayu merupakan salah satu kampung kota di Kota Semarang yang sedang mengalami gejala gentrifikasi. Kebertahanan kampung Sekayu saat ini semakin dipertanyakan apakah dapat terus dipertahankan atau tidak dengan kondisi pengembangan property di sekitarnya. Kondisinya saat ini cenderung dianggap tidak mampu bertahan seiring perubahan pemanfaatan ruang yang terdapat di lokasi tersebut untuk mendukung fungsi-fungsi ruang di sekitarnya (Evansyah \& Dewi, 2014). Penguasaan bangunan rumah yang berada di belakang Mall Paragon sudah banyak beralih kepemilikan menjadi kepemilikan perusahaan yang notabene adalah pengelola Paragon. Kondisi Kampung Sekayu yang juga merupakan salah satu kawasan permukiman kumuh yang termuat dalam SK Walikota Semarang Nomor 050/801/2014 dengan luasan total kumuh kota Semarang adalah 415,83 hektar dengan luasan kumuh kampung Sekayu adalah 2,3 hektar dan semakin terjepit dengan pembangunan di sekitarnya. Rencana baru 
kedepannya adalah pengembangan Mall Paragon II yang berlokasi persis di sebelah Mall paragon saat ini. Salah satu cagar budaya yang terdapat di Kampung Sekayu adalah Mesjid Taqwa yang dibangun pada tahun 1413 dan harus tetap dipertahankan.

Penanganan kawasan kumuh di Kampung Sekayu sudah dilakukan melalui program KOTAKU yang selesai tahun 2017 dan di nyatakan sudah bebas kumuh oleh tim KOTAKU Semarang. Namun dalam pantauan dilapangan kondisi kekumuhan tersebut masih terlihat cukup jelas. Kerapatan bangunan dan Koefisien dasar bangunan (KDB) yang rata-rata sudah mencapai 80-90\%, selain itu terlihat jelas ketidakteraturan bangunan. Dengan kondisi tersebut, tidak menutup kemungkinan kekumuhan itu akan terus berlanjut dan kembali kumuh setelah dilakukannya penanganan. Kondisi penanganan juga tidak memperhatikan hak kepemilikan tanah di kawasan tersebut. Sehingga perlu adanya upaya mencari alternatif baru dalam pelaksanaan penanganan kumuh di perkotaan khususnya kawasan yang memiliki nilai ekonomi tinggi.

TDR adalah instrument perencanaan pemanfaataan lahan yang berbasis pada pasar dengan mentransfer suatu hak pembangunan dari suatu lokasi ke lokasi lainnya dengan tujuan tertentu seperti penanganan kawasan kumuh, pencegahan urban sprawl, perlindungan cagar budaya, pelestarian kawasan pertanian, perlindungan kawasan hutan, penambahan ruang terbuka untuk publik, dan lain sebagainya yang ditentukan oleh pemerintah dan bekerja sama dengan pemangku kepentingan lainnya atau yang merupakan kesepakatan bersama antar pemangku kepentingan (Aken, Eckert, Fox, \& Swenson, 2008; Chan \& Hou, 2015; Janssen-Jansen, Spaans, \& Veen, 2008; Linkous, 2017; Nelson, Pruetz, \& Woodruff, 2013). Kompensasi nonfinansial juga dilakukan pemerintah ketika seseorang atau badan usaha yang berkepentingan dengan tanah atau lahan telah kehilangan sebagian hak atas property diatasnya dengan menciptakan hak property yang baru yang dapat dijual atau digunakan untuk suatu kepentingan tertentu yang kebanyakan adalah untuk kepentingan umum. Kompensasi non-finansial sebagai suatu insentif bagi perkembangan tata ruang menjadi semakin menarik dan banyak di gunakan dalam praktik perencanaan tata ruang. dalam penelitian ini salah satu tujuan perencanaan yang hendak dicapai adalah untuk penanganan kawasan kumuh.

Salah satu fungsi penting dari TDR adalah untuk mendistribusikan ulang hak pengembangan secara spasial dalam mendukung tujuan perencanaan publik, misalnya, pelestarian bangunan bersejarah atau lahan pertanian, juga untuk keterjangkauan perumahan serta dalam rangka melakukan efisiensi fiscal APBD karena pelaksanaannya berdasarkan mekanisme pasar (Aken et al., 2008; Pruetz \& Pruetz, 2007). Menurut Aken et al., (2008) terdapat tiga fitur utama dalam TDR:

i. Bersifat Sukarela; pemilik lahan baik area pengirim dan penerima sama-sama secara sukarela ikut berpartisipasi.

ii. Berbasis pasar; instrument TDR ini muncul semakin banyak karena untuk menfasilitasi kebutuhan pasar dan sebaiknya dalam menjual hak pembangunan yang akan di alihkan harus melalui pasar

iii. $\quad$ Fleksibel; TDR sangat fleksibel dalam pelaksanaannya, tidak hanya untuk mencapai suatu tujuan tertentu, namun bisa dimanfaatkan untuk banyak tujuan perencanaan.

Kompensasi non finansial sebagai instrumen perencanaan modern berakar pada konsep TDR Amerika mencakup semua situasi di mana pemerintah harus memberi kompensasi kepada pemilik tanah karena kehilangan kesempatan atau usahanya, tetapi memilih untuk tidak melakukannya dengan penggantian dalam bentuk nominal uang, tetapi dengan memberinya kesempatan membangun baru yang dapat dijual atau digunakan (Aken et al., 2008; Chan \& Hou, 2014; Linkous, 2017; Menghini, Gemperle, Seidl, \& Axhausen, 2015; Nelson et al., 2013). Kompensasi tersebut juga ada ketika pemerintah selaku otoritas perencanaan memberikan kompensasi atau insentif bagi pengembang untuk mewujudkan tujuan perencanaan tertentu baik di tanah mereka atau di tanah orang lain dengan menciptakan hak pengembangan yang dapat digunakan atau dijual (Janssen-Jansen, Spaans, \& Veen, 2008)

Beberapa pelaksanaan yang sudah dilaksanakan di beberapa Negara terkait TDR skema kompensasi non finansial (Janssen-Jansen, Spaans, \& Veen, 2008) adalah Jepang dengan distrik Marunouchi pada tahun 1986-1991, Korea Selatan pada Isoo Stasion tahun 2003 dengan mengembangkan kawasan kumuh nya, dan 
Spanyol di kawasan Prriols Valencia yang dimulai pada tahun 1988 dan selesai tahun 2001. Kesamaan utama dari ketiga Negara tersebut adalah pengembangan yang dilakukan dengan melibatkan pengembang. Dan pemerintah berperan dalam memberikan insentif bonus ketinggian bagi pengembang untuk mendapatkan keuntungan. Lokasi pengembangan juga merupakan lahan pribadi bukan lahan pemerintah. Ketiga conoh tersebut pengembangannya dengan konsep konsolidasi tanah vertikal. Terkait peraturan khusus yang mengatur konsep TDR dengan Konsolidasi tanah vertikal tersebut, ketiga Negara tidak ada upaya atau membuat regulasi khusus, hanya mengikuti aturan-aturan yang sudah ada dengan sedikit penambahan aturan untuk melengkapi. Dari contoh di tiga Negara tersebut, salah satu hal yang mendukung pelaksanaan itu bisa terjadi adalah adanya partisipasi dan peran serta masyarakat dalam pengembangannya. Keberhasilan TDR sangat dipengaruhi oleh ada tidaknya inisiator dari konsep tersebut. Inisiator atau pemrakarsa dari TDR ini bisa saja dari para petani, pemilik lahan selain pertanian yang berada di area-area yang memiliki fungsi kawasan terbatas, pengembang, lembaga lainnya yang berkaitan dan pemerintah itu sendiri (Nelson et al., 2013). Dari ketiga Negara tersebut diatas, salsh satu contoh dengan inisiatornya dari masyarakat adalah contoh yang erjadi di Sorea Selatan Isoo Stasion.

Proyek penanganan kumuh di Indonesia sudah melibatkan masyarakat dengan konsep Tridaya dengan tujuan agar pengawasannya dapat dilakukan oleh masyarakat setempat agar terjaga kondisi lingkungan yang sudah mendapat penanganan dan tidak kumuh kembali (Andini, 2013). Upaya peningkatan lingkungan kumuh yang sudah banyak dijalankan tidak menuntaskan kekumuhan itu sendiri dan belum mampu mengangkat potensi ekonomi masyarakatnya sehingga perlu di evaluasi untuk mendapatkan metode baru (Jaitman \& Brakarz, 2013), karena seharusnya penanganan kawasan kumuh dapat memberikan dampak pada peningkatan ekonomi masyarakatnya khususnya bagi masyarakat berpengasilan rendah (MBR) yang tinggal pada kawasan tersebut (R. Haryanto \& Ramdani, 2013). Telah banyak program penanganan yang di laksanakan oleh pemerintah pusat maupun daerah dengan istilah yang berbeda beda setiap masanya sejak tahun 1969 Kampung Improvement Program (KIP) dimulai hingga tahun 2015 dengan program KOTAKU namun belum mampu memberikan hasil yang maksimal. Apa yang sudah dikerjakan terdahulu, saat ini sudah kembali kumuh lagi khususnya di daerah perkotaan (Muta'ali \& Nugroho, 2016; Supriatna \& Van Der Molen, 2014). Dalam setiap program yang sudah dilaksanakan tersebut, belum terlihat adanya peran swasta yang signifikan dalam upaya penanganan kawasan kumuh. Melibatkan swasta dalam penanganan kumuh ini juga dapat membantu dalam menghidari gentrifikasi. Gentrifikasi sudah lama terjadi di kampung kota di Semarang bahkan ada yang telah menghilangkan seluruh penduduk asli setempat berikut dengan kearifan sosial dan budaya yang ada didalamnya berganti dengan bangunan tinggi dengan fungsi perdagangan dan jasa seperti hotel dan supermarket (Wilonoyudho, 2014). Gentrifikasi ini juga sering kali hadir ketika penanganan kawasan kumuh susah dilakukan di kawasan permukiman kumuh dikarenakan fasilitas dasar permukiman sudah tersedia di dalamnya dan adanya perbaikan kondisi lingkungan (Supriatna \& Van Der Molen, 2014).

Latar belakang dari penelitian ini adalah tidak tuntasnya penanganan kumuh yang sering dilaksanakan oleh pemerintah dengan cara-cara konsvensional khususnya yang berada di pusat kota dengan kondisi kekumuhannya dikarenakan kerapatan dan ketidakteraturan bangunan. Berdasarkan ulasan diatas, penelitian ini bertujuan untuk mengkaji Konsep Transferable Development Right (TDR) dengan skema kompensasi non finansial dalam upaya penanganan kumuh kawasan perkotaan khususnya untuk kawasan Kelurahan Sekayu, Semarang. Peneliti telah mencoba mencari penelitian yang terkait dengan hal ini di Indonesia namun belum menemukan satupun diantaranya. Konsep TDR juga merupakan hal yang baru dalam perencanaan di Indonesia khususnya di bidang pemanfataan ruang dan lahan. Konsep ini diharapkan dapat menjadi solusi baru daripada tetap mempertahankan cara-cara konvensional yang biasa dilakukan oleh pemerintah. Metode penelitian yang digunakan dalam penelitian ini adalah dengan metode kualitatif dengan melakukan wawancara, observasi dan kajian-kajian literature sebagai pembanding. Manfaat dari penerapan konsep TDR tersebut diharapkan dapat menghemat dana APBD dalam penyediaan fasilitas publik 
perkotaan dan upaya penanganan kumuh dengan menghadirkan pengembang dan partisipasi masyarakat. Di sisi lain pengembangan kota yang lebih terarah dan terencana dapat dilakukan.

\section{DATA DAN METODE}

Data- data utama yang dibutuhkan dalam penelitian ini adalah merupakan data primer berupa tanggapan dari para pemangku kepentingan terhadap upaya penerapan konsep TDR skema kompensasi non finansial dalam penanganan kawasan kumuh di Kelurahan Sekayu. Metode yang digunakan dalam penelitian ini adalah metode kualitatif yang menurut Moleong, (2002) adalah penelitian yang bermaksud untuk memahami fenomena tentang apa yang dialami oleh subyek penelitian seperti perilaku, persepsi, motivasi, tindakan, dll, secara holistik, dan dengan deskripsi dalam bentuk kata-kata dan bahasa, pada suatu konteks khusus yang alamiah dan dengan memanfaatkan berbagai metode alamiah. Penelitian ini merupakan penelitian kualitatif deskriptif yang mencoba menggambarkan kegiatan penelitian dengan mengkaji suatu konsep yang relative baru di bidang perencanaan tata guna lahan dalam upaya penanganan kawasan permukiman kumuh dan sekaligus sebagai upaya pengembangan kota Semarang dengan melakukan wawancara dan forum group diskusi dengan masyarakat serta melakukan telaah literatur yang terkait dengan konsep pelaksanaan.

Data dan informasi terkait penelitian ini dihimpun dengan melakukan forum group diskusi dengan masyarakat dilokasi penelitian dan wawancara dengan stakeholder yang berkaitan erat dengan pelaksanaan konsep TDR tersebut serta melakukan observasi lapangan dan studi literartur. Penelitian dengan menggunakan data primer melalui diskusi dan wawancara mendalam guna mencari informasi sebanyakbanyaknya dari responden dan observasi lapangan di perkuat dengan data sekunder yang didapat dari instansi terkait maupun dari kajian literartur yang menjadi acuan dalam penilitian ini. Responden yang menjadi sasaran dalam penelitian ini dibagi menjadi 3 bagian yang utama yaitu;

1. Masyarakat Kampung Sekayu sebagai kawasan yang akan dilaksanakan penanganan kumuh. Pelaksanaan diskusi dengan masyarakat dilakukan dengan para tokoh masyarakat yang ada di kelurahan Sekayu antara lain : Lurah Sekayu, Ketua lembaga masyarakat setempat, dan RW dan RT setempat.

2. Pengembang dari Asosiasi REI mewakili pihak swasta dan Perumnas mewakili BUMN

3. Pemerintah Daerah Kota Semarang

\section{Gambaran Wilayah Studi}

Kampung Sekayu merupakan salah satu kampung yang berada di Kelurahan Sekayu Kecamatan Semarang Tengah, Kota Semarang. Kekumuhan di lokasi penelitian ini sebenarnya sudah banyak mendapatkan penanganan dari pemerintah baik itu melalui pemerintah pusat maupun pemerintah daerah dalam penyediaan infrastruktur dasar permukiman. Namun dari sisi kerapatan bangunan dan ketidakteraturan bangunan yang ada serta tidak adanya ruang terbuka hijau menyebabkan kampung ini masih selalu identik dengan kekumuhan. Posisi kampung Sekayu yang berada di area strategis pusat kota Semarang menjadikannya sangat diminati oleh para pengembang dalam upaya bisnis property. Di dalam Kampung Sekayu tersebut terdapat satu Masjid (at-Taqwa) yang merupakan salah satu cagar budaya yang di lestarikan yang di bangun pada tahun 1413. Upaya pemerintah dalam menetapkan Kampung Sekayu sebagai kampung yang dipertahankan belum memadai karena belum ada perencanaan khusus dalam upaya bagaimana kampung tersebut akan dipertahankan. 
Pangaribuan, Haryanto/ Jurnal Pembangunan Wilayah dan Kota, Vol.15, No.2, 2019, 108-121 Doi: https://doi.org/10.14710/pwk.v15i2.21435

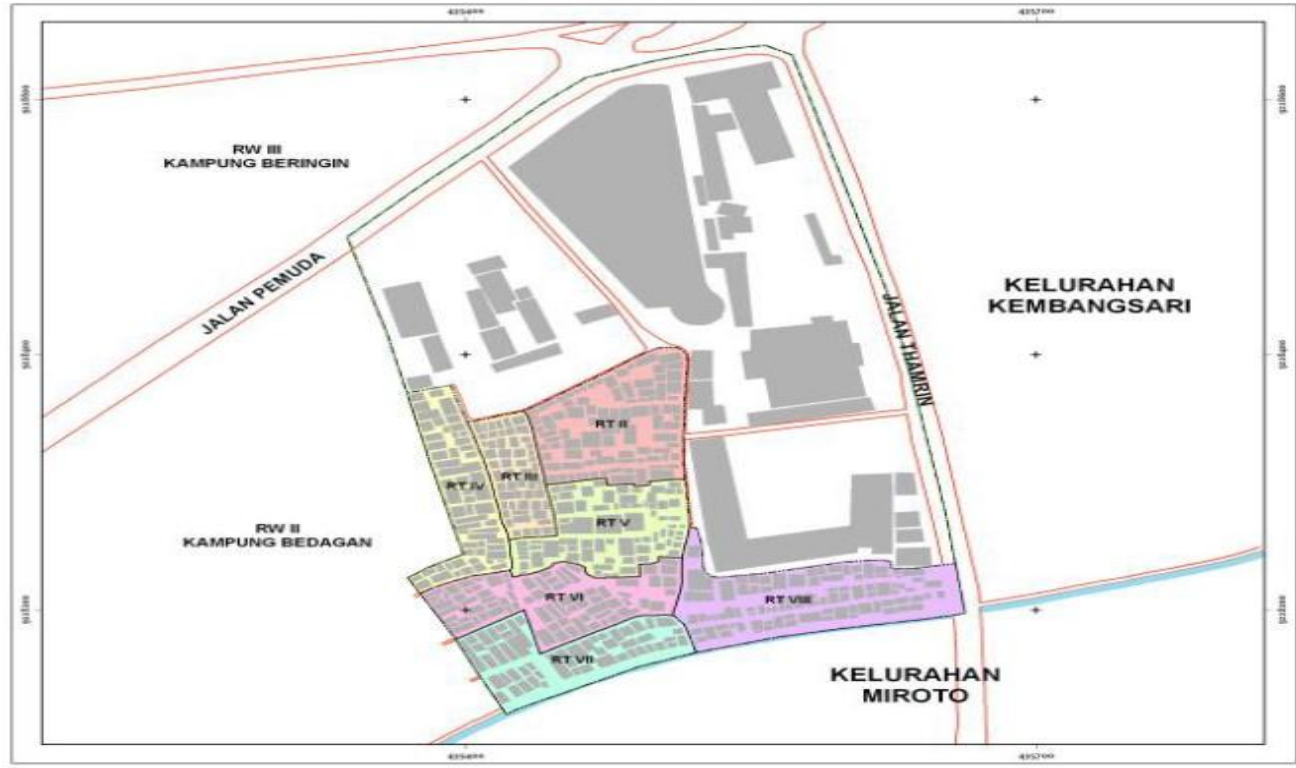

Gambar 4. Kampung Sekayu (sumber Bappeda 2013)

Tata Guna Lahan di Kelurahan Sekayu

Tata guna lahan di Kelurahan Sekayu di dominasi untuk permukiman selebihnya untuk perkantoran, perdagangan, jasa, pendidikan serta taman/ruang terbuka hijau. Di Kelurahan Sekayu juga merupakan pusat Pemerintahan Kota Semarang.

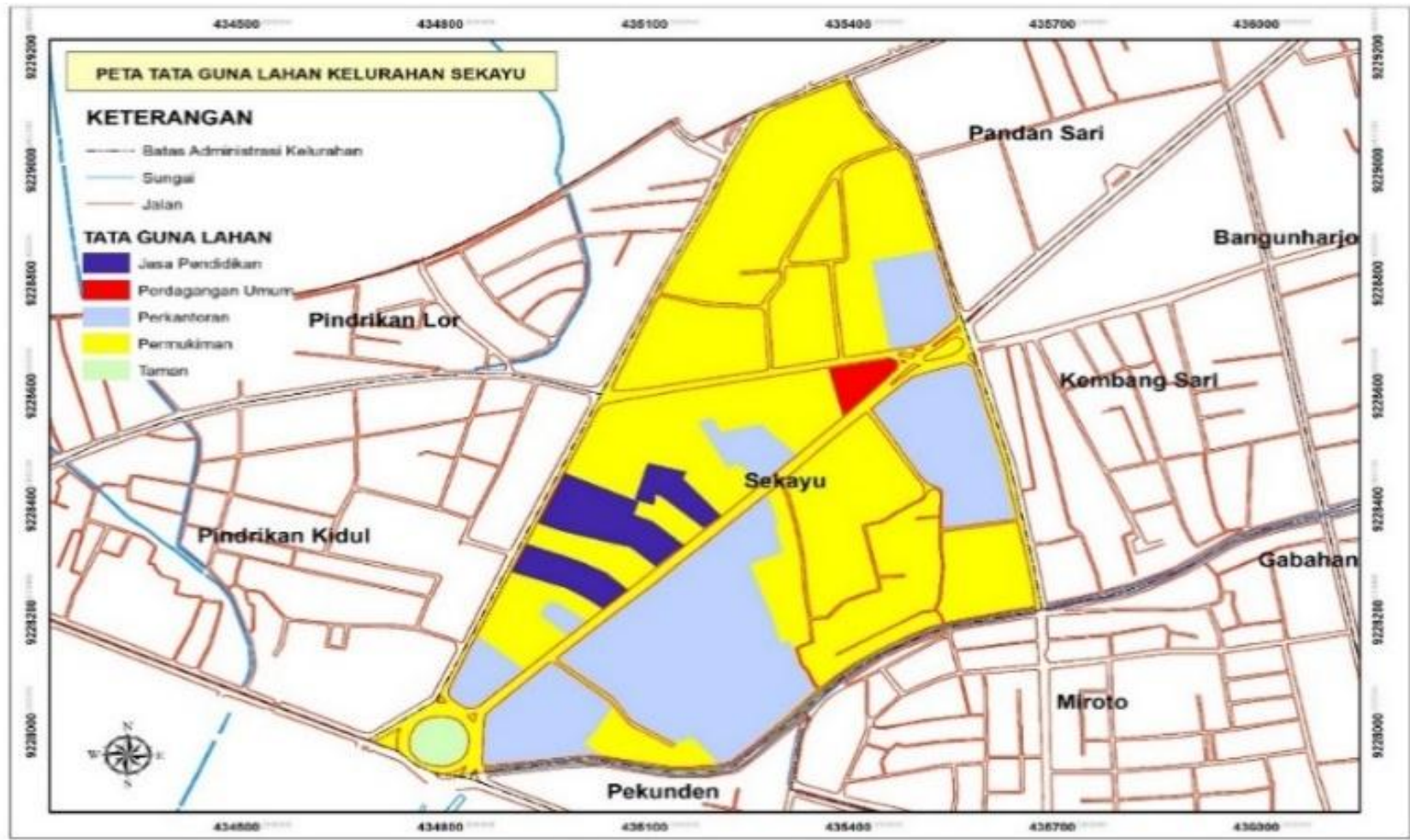

Gambar 5. Peta Tata Guna Lahan Kelurahan Sekayu (sumber; KOTAKU 2017) 


\section{Kondisi Perekonomian Masyarakat dan Kependudukan}

Dari table 1 terlihat bahwa tingkat kesejahteraan masyarakat Sekayu masih didominasi oleh keluarga prasejahtera dan keluarga sejahtera 1 dengan total $41,4 \%$, dengan kata lain, masyarakat miskin dan sangat miskin masih relative lebih besar dibandingkan dengan masayarakat yang berpenghasilan menengah ke atas. Dilihat dari kependudukannya, jumlah penduduk di kelurahan Sekayu tahun 2017 berdasarkan data profil Kelurahan Sekayu adalah sejulmah 3.876 penduduk dengan jumlah kepala keluarga sebanyak 858 KK dan rata-rata kepadatan penduduk $6.814 \mathrm{jiwa} / \mathrm{km} 2$.

Tabel.1 Tabel tingkat kesejahteraan masyarakat Kelurahan Sekayu

\begin{tabular}{llcc}
\hline No & Tingka Kesejahteraan & Jumlah & Prosentase \\
\hline 1 & Keluarga Prasejahtera & 111 & $12,9 \%$ \\
2 & Keluarga Sejahtera 1 & 245 & $28,5 \%$ \\
3 & Keluarga Sejahtera 2 & 268 & $31,3 \%$ \\
4 & Keluarga Sejahtera 3 & 151 & $17,6 \%$ \\
5 & Keluarga Sejahtera 3+ & 83 & $9,7 \%$ \\
6 & Total Jumlah Kepala Keluarga & 858 & $100 \%$ \\
\hline
\end{tabular}

Sumber: Profil Kelurahan Sekayu 2017

\section{Kondisi Sosial Budaya}

Kelurahan Sekayu yang merupakan cikal bakal berdirinya Kota Semarang memiliki nilai historis yang tinggi. Salah satu peninggalan budaya yang masih terjaga disana adalah masjid at-taqwa yang dibangun pada tahun 1413. Masjid tersebut merupakan masjid yang dibangun sebagai uji coba pembangunan masjid Demak. Dan menurut cerita masyarakat setempat Sekayu merupakan singkatan dari Sentra Kayu, dimana pada dulunya daerah tersebut sebagai tempat pengumpulan kayu Jati yang akan digunakan untuk pembangunan masjid Demak.
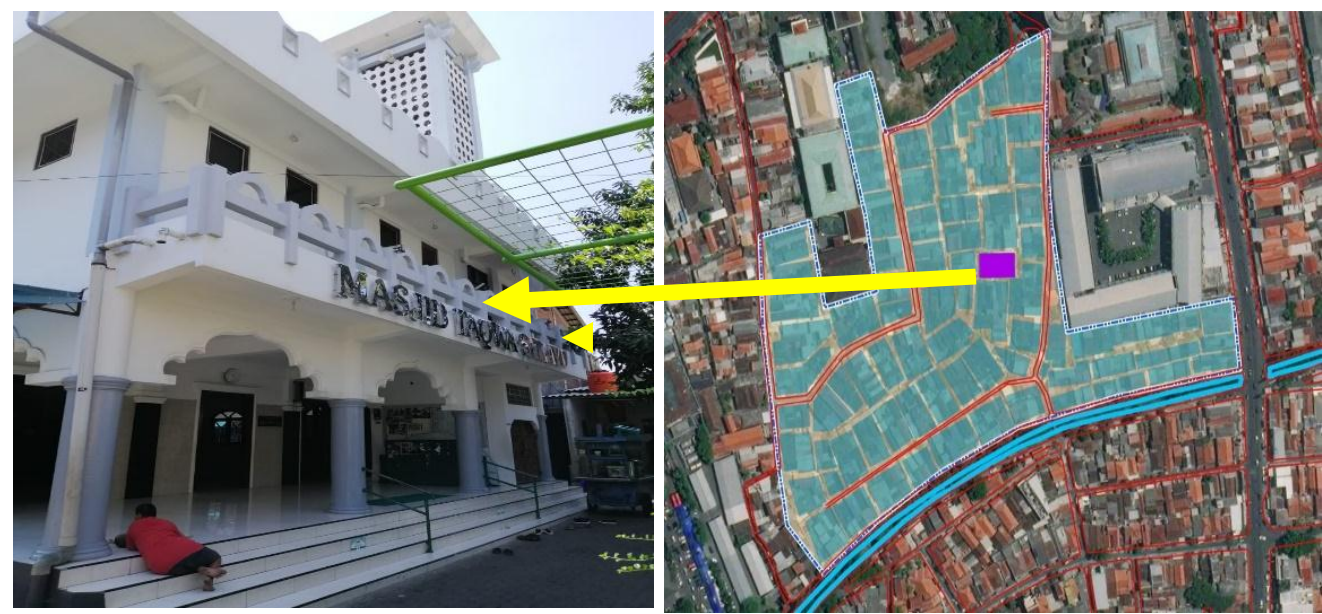

Gambar 6. Masjid At-Taqwa Sekayu

Karakteristik sosial budaya masyarakat Sekayu saat ini sudah mulai terkikis seiring semakin banyaknya masyarakat pendatang yang merupakan pekerja di sekitar Sekayu yang menempati kelurahan Sekayu. Meningkatnya jumlah penduduk yang tinggal di kelurahan Sekayu yang berasal dari luar menjadi 
salah satu faktor penyebab terkikisnya sosial budaya setempat disamping semakin banyaknya masyarakat setempat yang sudah tidak menempati rumahnya Karena di fungsikan sebagai rumah kontrakan ataupaun kos-kosan.

\section{HASIL DAN PEMBAHASAN}

\subsection{Konsep TDR ditawarkan}

Pada langkah awal, peneliti melakukan diskusi yang dilaksanakan di Kelurahan Sekayu bersama dengan tokoh masyarakat setempat, peneliti mencoba menawarkan ilustrasi pengembangan kawasan Kampung Sekayu dengan melaksanakan Konsolidasi Tanah Vertikal (Gambar 7), dimana kawasan tersebut akan dibangun dan dikembangkan tanpa menggusur masyarakat yang telah tinggal di dalamnya. Selain itu, konsep pengembangannya juga ditawarkan pada pengembang (pengalihan hak pengembangan/TDR) tidak dengan pembagian lahan bersama pengembang melainkan dengan kerjasama diatas lahan masyarakat. Konsep ini diadopsi dari salah satu contoh di Korea Selatan Isoo Stasion yang mengembangkan kawasan permukiman menjadi kawasan campuran yang di dalamnya terdapat apartemen, mall, perkantoran dan stasiun kereta.

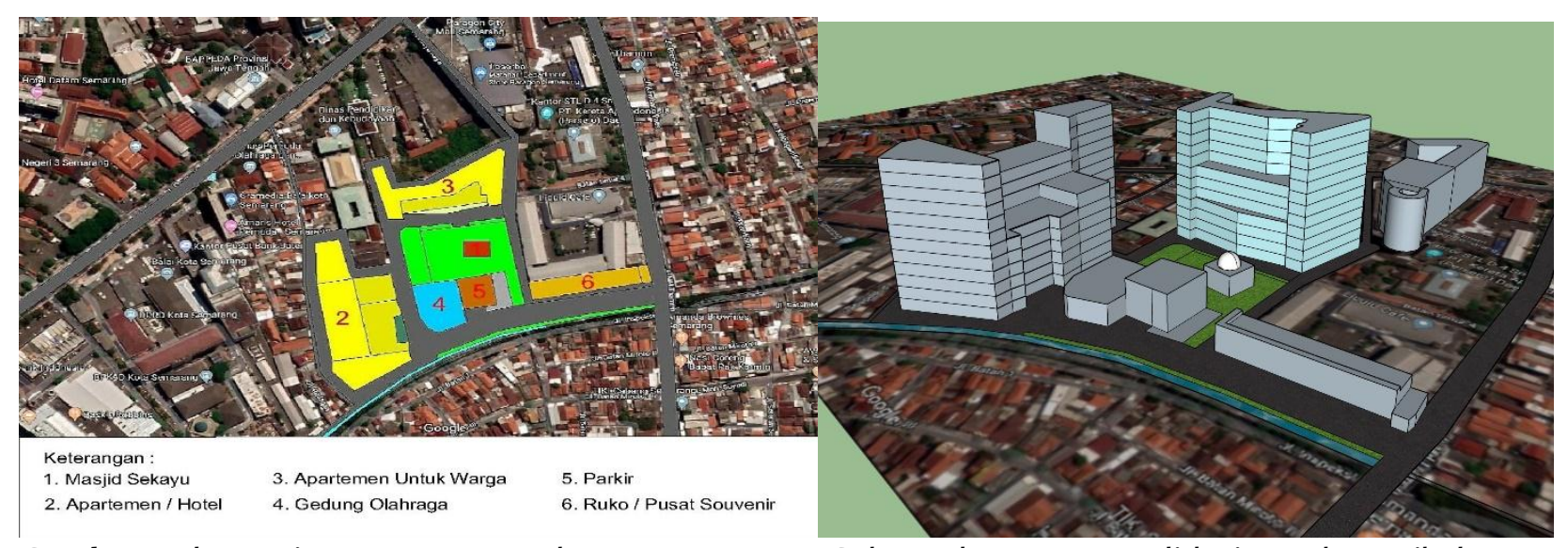

Gambar 7. Ilustrasi Konsep Pengembangan Kampung Sekayu dengan Konsolidasi Tanah Vertikal

Pada ilustrasi tersebut, peneliti mencoba mengkonsep pengembangan dengan mengedepankan penyediaan ruang terbuka hijau dan untuk pelestarian kawasan cagar budaya yang terdapat di dalam nya. Selain itu, upaya pengembangan yang ditawarkan kepada pengembang juga harus dapat memfasilitasi kebutuhan masyarakat untuk dapat meningkatkan kesejahteraannya dan adanya keadilan terkait besaran nilai asset yang dimiliki sebelum pengembangan harus minimal sama dengan setelah pengembangan. Konsep pengembangan yang ditawarkan juga pembangunannya dilakukan secara bertahap untuk meminimalkan besarnya biaya pemindahan masyarakat yang terkena dampak pembangunan. Ilustrasi tersebut diharapkan dapat menjadi gambaran awal bagi pemangku kepentingan dapat memahami konsep TDR dengan pelaksanaan dalam bentuk Konsolidasi Tanah Vertikal dan peneliti lebih lanjut dapat meminta pendapat para pemangku kepentingan tersebut terkait konsep tersebut apakah mau menerimanya atau tidak.

Konsolidasi tanah vertikal (KTV) ini merupakan salah satu bentuk TDR yang lazim dilakukan dalam studi literatur yang sering di temukan terkait TDR khususnya di Jepang, Spanyol, Korea Selatan dan beberapa Negara lainnya. Di Indonesia sendiri pada dasarnya sudah pernah melakukannya dalam bentuk konsolidasi tanah horizontal yang di mulai dari program KIP dilanjutkan dengan pembangunan rusun di beberapa lokasi di Indonesia dalam upaya penanganan kawasan kumuh, namun pelaksanaannya umumnya yang berada di tanah Negara dan bekerjasama dengan Perumnas. Konsep TDR nya sebenarnya sudah terlihat dengan 
adanya pengalihan hak pengembangan kepada pihak pengembang dan menempatkan perumahan yang kumuh tersebut dalam plot tertentu dalam kawasan pengembangan. Namun dalam pengembangan dengan membangun rusunawa yang bekerjasama dengan Perumnas belum bisa di sebutkan sebagai salah satu konsep KTV yang menjadi bagian dari TDR dikarenan pembiayaannya merupakan dana APBN/APBD. Konsep TDR ini muncul sebagai salah satu bantuan bagi pemerintah dalam keterbatasan dana dalam upaya pengembangan seperti yang terjadi di banyak Negara yang sudah melaksanakannya. Partisipasi masyarakat secara sukarela juga sudah didapatkan sehingga konsolidasi tanah vertikal dari rumah tapak ke rumah susun milik dapat dilakukan. Dari kepemilikan tanahnya, umumnya tanah tersebut adalah milik pemerintah, sehingga pelaksanaannya lebih mudah jika di bandingkan dengan kepemilikan yang kebanyakan oleh masyarakat. Kondisi kepemilikan tanah di Kelurahan Sekayu khususnya di kampung Sekayu adalah hak milik walau belum semua mensertifikatkan tanah yang dimiliki. Jika dilihat dari sejarahnya, harusnya masyarakat sudah dapat memiliki tanah tersebut karena sudah dihuni secara turun temurun. Tahun 1998 dan 1999 sesuai dengan informasi yang didapatkan dari Kantor Pertanahan Kota Semarang pernah dilakukan pengkuran hampir mencakup 90 \% kelurahan Sekayu di kampung Sekayu dan kampung Bedagan, namun belum diketahui penyebabnya kenapa tidak semua mensertifikatkan dari hasil pengukuran tersebut.

\subsection{Tanggapan Stakeholder Terkait KTV di Kampung Sekayu}

1.Tanggapan Tokoh Masyarakat di Kampung Sekayu

Hasil diskusi yang dilakukan pada tanggal 28 September 2018 bertempat di Kelurahan Sekayu, peserta yang hadir berjumlah 20 orang termasuk di dalamnya Pak Budi selaku Lurah Sekayu. Dari ilustrasi yang ditawarkan kepada peserta diskusi tersebut, tidak terlihat adanya penolakan setelah peneliti menyampaikan maksud dan tujuan pelaksanaan KTV tersebut di kampung Sekayu. Namun pelaksanaannya tidak mungkin di lakukan hanya mengikuti pendapat tokoh masyarakat tersebut, sehingga peserta diskusi meminta jika memang akan dilaksanakan perlu dilakukan pendekatan dan sosialisasi terkait konsep pengembangan tersebut kepada masyarakat secara keseluruhan dan dengan tegas menyatakan akan mengikutinya jika pelaksanaannya merupakan salah satu kebijakan yang ditetapkan oleh pemerintah Kota Semarang. Selain itu, peserta diskusi juga meminta kejelasan terkait bagaimana perhitungan asset mereka dengan pelaksanaan konsep tersebut.

Terkait desain pengembangan kawasan, masyarakat setempat juga harus dilibatkan untuk melihat bagaimana mereka kedepannya dapat berinteraksi dan potensi bagi masyarakat untuk dapat meningkatkan kesejahteraan mereka jika mereka tinggal di dalam rusun/apartemen. Hal ini menjadi penting dikarenakan biaya hidup untuk tinggal di dalam rusun dan apartemen akan lebih tinggi jika mereka hidup dalam kondisi saat ini. Karenanya peningkatan kesejahteraan masyarakat menjadi penting untuk diperhatikan. Sekaligus menjadi evaluasi bagi pelaksanaan KTV yang dilakukan pemerintah selama ini yang hanya sekedar memindahkan masyarakat ke dalam rusun dari lingkungan permukiman kumuh tanpa memperhatikan potensi kesejahteraan masyarakat yang sebelumnya menjadikan rumah nya menjadi sarana untuk mendapatkan penghasilan.

\section{Tanggapan Pengembang}

- DPD REI Jawa Tengah

Membicarakan konsep TDR dengan skema kompensasi non finansial pada awalnya masih belum familiar bagi banyak kalangan di Indonesia termasuk dengan DPD REI Jawa Tengah. Namun ketika disampaikan bahwa salah satu dari konsep TDR tersebut berupa pelaksanaan KTV baru memahami. Seperti disampaikan pada bab sebelumnya terkait konsolidasi tanah, penataan kawasan dengan realokasi merupakan salah satu bentuk TDR yang lazim dilaksanakan di banyak Negara yang sudah melaksanakan konsep TDR tersebut. Indonesia dengan KIP nya pada dasarnya di beberapa literature disebutkan juga sudah melaksanakan. Namun dalam evaluasi akhir terkait KIP tersebut bahwa lokasi 
yang sudah di tata sebelumnya saat ini sudah kembali kumuh lagi sehingga perlu dilakukan penanganan lagi karena sudah kembali masuk kategori kumuh. Sehingga perlu terobosan baru terkait pelaknsaan konsolidasi tanah tersebut yang tadinya masih bersifat horizontal saat ini diupayakan menjadi konsolidasi tanah vertikal.

Menurut Bapak Prijanto ketua DPD REI Jawa Tengah terkait konsep pelaksanaan KTV tersebut jika dilaksanakan di Kampung Sekayu adalah bahwa hal tersebut sangat mungkin dilaksanakan dan akan berdampak baik pada kawasan tersebut. Namun beliau meragukan bagaimana dengan kesiapan seluruh masyarakat, karena umumnya terdapat masalah pelaksanaan konsolidasi tanah dengan bekerjasama dengan pengembang adalah bagaimana menyatukan seluruh keinginan masyarakat yang terkena dampak pengembangan dengan konsolidasi tanah tersebut. Lebih lanjut menurut Prijanto bahwa pengembang bersedia mengembangkannya, dengan harapan membantu pemerintah mengatasi permukiman kumuh, kedua menyediakan rumah layak huni, ketiga memberikan pengembangan kota yang menguntungkan bagi pengembang.

Terkait kepemilikan tanah, Prijanto membedakan 3 kategori yaitu lahan milik pemerintah, kedua adalah milik pengembang atau badan usaha, terakhir adalah milik masyarakat yang memiliki sertifikat.

"Yang tersulit untuk dijalankan kerjasama pengembangannya adalah milik masyarakat karena membutuhkan waktu yang lama untuk menyatukan keinginan masyarakat, namun tidak menutup kemungkinan juga untuk dilaksanakan dengan adanya pembagian lahan yang akan dikembangkan buat pengembang dan lahan untuk pembangunan tempat tinggal vertikal bagi masyarakat beserta fasilitas pendukungnya."

Konsep kerjasama bagi lahan tersebut juga sudah diterapkan di beberapa lokasi di Indonesia dengan bekerjasama dengan pemerintah namun ada juga yang pengembangannya dengan system BOT (Built, Operation,Transfer). Beberapa lokasi tersebut adalah pembangunan terminal dan pasar tradisional di Klaten dengan luasan 2 ha. Terminal dan pasar tradisional diserahkan kepada pemerintah sedangkan pengembangnya mendapatkan pengelolaan di depan Mall nya.

Secara umum menurut ketua DPD REI Jawa Tengah bahwa konsep tersebut :

"Pengembang bersedia mengembangkannya, dengan harapan membantu pemerintah mengatasi permukiman kumuh, kedua menyediakan rumah layak huni, ketiga memberikan pengembangan kota yang menguntungkan bagi pengembang"

Sebagai catatan tambahan dari beliau menyampaikan bahwa pengembangan ini juga akan bersifat politis juga kedepannya mengingat kawasan-kawasan yang menjadi pengembangan tersebut merupakan kantong-kantong suara politikus yang sedang duduk di DPRD.

- Perumnas Regional V Semarang

Tidak jauh berbeda dengan pertemuan REI, Perumnas Regional $V$ Semarang juga masih berlum banyak mengerti terkait konsep TDR yang akan didiskusikan sebelum disampaikan terkait pelaksanaannya dalam bentuk KTV. Dalam pertemuan dengan Perumnas Regional V Semarang, General Manager Regional V Semarang Bapak Langgeng menyampaikan pendapatnya terkait konsep KTV tersebut sangat baik jika bisa dilaksanakan dalam upaya urban redevelopment atau peremajaan kota. Dalam kesempatan tersebut beliau menyampaikan bahwa Perumnas selama ini sudah sering dalam melakukan peremajaan seperti yang peneliti sampaikan namun umumnya dilakukan diatas lahan pemerintah dan lebih banyak proses relokasi dari kawasan kumuh di pindah ke tempat lain dengan konsep rusunami atau rusunawa. Senada dengan apa yang disampaikan pihak REI Kota Semarang, bahwa jika lahannya berada diatas tanah masyarakat akan lebih sulit dilakukan karena dibutuhkan waktu dan proses yang panjang dalam upaya menyatukan apa yang menjadi keinginan masyarakat banyak yang terkena dampak pengembangan bahkan Perumnas harus menggandeng pakar dari sosiolog untuk membantu dalam memberikan sosialisasi pada masyarakat. Jika diatas tanah pemerintah akan lebih mudah karena masyarakat umumnya akan ditangani oleh pihak pemerintah, sehingga 
pengembang tinggal melaksanakan saja. Saat jaman orde baru di bawah pemerintahan Presiden Soeharto dikala Perumnas masih menjadi perpanjangan tangan pemerintah langsung dalam penyediaan perumahan tidak banyak kendala yang dihadapi terkait upaya pengembangan kawasan untuk dibangunkan rusunawa atau rusunami seperti contoh yang pernah dilaksanakan di Kemayoran Jakarta Pusat, Kelender Jakarta Timur, dan di Palembang.

Melihat gambaran lokasi penelitian Kampung Sekayu, Langgeng menyatakan kawasan tersebut memang sangat padat dan akan menyulitkan untuk pengembangan karena akses jalan di dalam perkampungan yang sangat sempit dan akan susah untuk memasukkan bahan baku untuk pembangunan. Selain itu tidak terdapat lahan kosong untuk pembangunan hunian vertikal bagi masyarakat yang terkena dampak sehingga bagaimanapun tetap harus menggusur sebagian kawasan untuk dilakukan pembangunan tahap awal sebelum mengembangkan seluruh kawasan yang ditunjukkan dalam gambar 4 dan gambar 6 . Jalan Thamrin adalah satu-satu nya akses jalan besar yang paling memungkinkan untuk menuju lokasi pengembangan, namun jalur tersebut merupakan satu arah sehingga akan menyulitkan juga dalam distribusi bahan baku menuju lokasi. Peran Pemda sangat penting dalam hal ini, khususnya terkait perijininan. Pada dasarnya Perumnas mau untuk ikut berpartisipasi dalam konsep tersebut dengan prisip kehati-hatian, utamanya dalam pembuatan desain pengembangan terkait ketinggian bangunan karena berkaitan dengan jalur penerbangan atau Kawasan Keselamatan Operasi Penerbangan (KKOP) bandara Ahmad Yani Semarang. Adanya pembatasan ketinggian terkait KKOP menjadikan pembuatan desain juga harus sangat diperhitungkan. Desain pengembangan dan ketinggian bangunan yang dapat dilaksanakan akan sangat berpengaruh bagi pengembang dalam upaya mendapatkan keuntungan dari proyek tersebut.

Perumnas sebelumnya dalam membuat konsep campuran seperti ilustrasi di atas belum pernah menargetkan masyarakat MBR sebagai sasaran konsumennya melainkan masyarakat menengah ke atas seperti yang dilakukan di Sentra Land Kota Semarang sebagai kawasan campuran yang berisi hunian, hotel, Mall, komplek perkantoran, hiburan, food court dalam satu bangunan. Terkait masyarakat MBR tinggal di rusun, Pak Langgeng selaku GM Perumnas Regional V menyampaikan:

"Salah satu permasalahannya dengan MBR adalah biaya hidup di rusun atau apartemen

bisa dikatakan cukup mahal karena adanya biaya-biaya yang harus dibayarkan penghuni rusun/apartemen seperti biaya service charge diluar biaya hidup sehari-hari lainnya."

Oleh karena itu, upaya peningkatan kesejahteraan masyarakat seperti yang disebutkan sebelumnya bagi masyarakat yang terkena dampak juga harus dipikirkan, dan hal itu bisa dapat dilakukan dengan menyediakan sarana food court di kawasan apartemen atau kawasan lainnya dengan perhitungan yang jelas agar sama-sama dapat menikmati keuntungannya. Menurut GM Regional V Perumnas tersebut terkait apartement di Kota Semarang masih lebih banyak berfungsi sebagi investasi karena tidak di huni oleh pemilik dalam kesehariannya.

Jika Perumnas ikut dalam proyek pengembangan untuk tujuan perencanaan kota seperti disebutkan di atas, mereka mengharapkan ada perlakuan khusus terkait perijinan agar dapat mengurangi ketidakpastian yang berujung pada pembengkakan biaya pengembangan. Lebih lanjut dikatakan bahwa Perumnas hanya akan ikut jika mendapat dukungan penuh dari pemerintah daerah.

\section{Tanggapan Pemerintah Kota Semarang}

Berdiskusi dengan Dinas Perumahan dan Permukiman (Disperkim) Kota Semarang terkait penanganan kawasan kumuh Kampung kota memberikan angin segar dalam penelitian ini. Konsep penataan kawasan permukiman kumuh dengan KTV merupakan suatu rencana penanganan kawasan kumuh dengan kriteria permukiman yang memiliki kepadatan dan ketidakteraturan bangunan yang memang sedang dikaji untuk dilaksanakan oleh Disperkim Kota Semarang. Penanganan kawasan kumuh di Kampung Sekayu, pemerintah kota Semarang masih melaksanakannya dengan cara 
konvensional melalui program KOTAKU dengan penyediaan fasilitas dasar berupa jalan, drainase, Ipal komunal, alat pemadam kebakaran, persampahan. Konsep KTV yang merupakan bagian TDR, Disperkim Kota Semarang sangat setuju dan sebenarnya juga berniat untuk mencobanya dengan melakukannya berdasarkan mekanisme pasar mengingat kampung Sekayu berada di kawasan strategis pusat kota Semarang.

Kompensasi yang bisa diberikan oleh pemerintah Kota Semarang terhadap pengembang yang ikut berperan dalam penanganan kawasan kumuh melalui KTV seperti yang di ilustrasikan, pemerintah kota Semarang melalui dinas Penataan Ruang nya menyampaikan bahwa tidak banyak yang dapat diberikan dikarenakan masalah perijinan sebenarnya di Semarang sudah mengikuti aturan kemudahan perijinan yang disampaikan oleh Presiden Jokowi. Kemudian ketika berbicara bonus Floor Area Ratio (FAR) yang dapat di berikan di Sekayu kepada pengembang juga tidak bisa diatur dalam RDTR Kota Semarang karena aturan ketinggian bangunan yang diatur oleh dinas penataan Ruang Kota Semarang hanya sebatas pada ketinggian gedung 5 lantai saja, selebihnya adalah merupakan kewenangan dinas perhubungan dalam kaitannya dengan KKOP Bandara Ahmad Yani Semarang. Dinas Penataan Ruang Semarang juga sudah sering mengupayakan ide perpindahan bandara Semarang keluar dari Kota Semarang agar perencanaan zonasi di Kota Semarang dapat lebih dimaksimalkan lagi. Kompensasi yang mungkin diberikan adalah kemudahan perijinan yang notabene sudah berjalan di Kota Semarang, selain itu penyediaan infrastuktur untuk pelaksanaan KTV tersebut juga apat diberikan karena merupakan insentif yang sudah di atur di dalam peraturan UU no 1 Tahun 2011. Terkait bagaimana TDR tersebut dapat dijadikan sebuah peraturan resmi di Kota Semarang seperti halnya yang sudah dilakukan pemerintah Kota Bandung dan DKI Jakarta, Pak Budi dari Bappeda masih membutuhkan waktu untuk hal tersebut karena perlu adanya kajian terlebih dahulu terkait hal tersebut. Dan upaya pengembangan Kampung Sekayu, menurut beliau tidak masalah dilakukan dengan konsep tersebur mengingat masyarakat dan pengembang sudah menyatakan kesediaannya, namun tetap harus memperhatikan kondisi cagar budaya yang terdapat di dalamnya. Pak Ferry dari Dinas Penataan Ruang Semarang menyampaikan terkait upaya memasukkan TDR dalam suatu kebijakan khusus :

"jadi..kita memangkas birokrasi, memangkas peraturan, ini dalam rangka, masyrakat itu dimudahkan terus gitu, tadi, mas nya sempat menyebutkan peraturan pak, TDR, kalau nafasnya, konsepnya TDR itu sudah masuk di dalam tata ruang ya saya kira ga perlu..gitu..maksud saya gitu"

Dari apa yang disampaikan beliau terkait upaya menjadikannya kebijakan khusus, bahwa hal tersebut masih dianggap tidak perlu selama aturan-aturan yang ada sekarang masih dapat menfasilitasi berjalannya konsep tersebut seperti halnya contoh di Spanyol bahwa disana tidak ada penambahan aturan baru terkait penerapan TDR tersebut.

Berkaitan dengan 3 fitur utama TDR, hasil kajian yang diperoleh dari tingkat penerimaan stakeholder dalam upaya penerapan TDR di Kampung Sekayu ditunjukkan dalam table berikut:

Tabel 2. Kesesuaian dengan Fitur TDR

\begin{tabular}{|c|c|}
\hline $\begin{array}{l}\text { Faktor Kunci } \\
\text { Pelaksanaan TDR }\end{array}$ & Keterangan \\
\hline Bersifat sukarela & $\begin{array}{l}\text { Masyarakat mau berpartisipasi dengan beberapa catatan utama yaitu: } \\
\text { 1. Kegiatan tersebut ditetapkan oleh pemerintah } \\
\text { 2. Ada sosialisasi lebih lanjut ke masyarakat } \\
\text { 3. Peningkatan ekonomi masyarakat (pemberdayaan masyarakat) }\end{array}$ \\
\hline Mekanisme pasar & $\begin{array}{l}\text { Diterimanya konsep ini pada beberapa pengembang (REI, PERUMNAS) telah memenuhi unsur terkait } \\
\text { pelaksanaan yg berbasis pasar dimana kedepannya konsep pelaksanaanya dapat di lelangkan untuk } \\
\text { mendapat pengembang yang sesuai }\end{array}$ \\
\hline Fleksibilitas & $\begin{array}{l}\text { Kebijakan terkait pelaksanaan TDR di Kota Semarang dapat disesuaikan dengan aturan-aturan yang } \\
\text { sudah ada dan terbuka peluang untuk membuat aturan yang sesuai dengan kebutuhan yang ada. }\end{array}$ \\
\hline
\end{tabular}




\section{KESIMPULAN}

Secara keseluruhan dari pemangku kepentingan menerima konsep TDR dengan skema kompensasi non finansial dengan catatan-catatan tersendiri. Dari fitur utama TDR juga sudah dapat dikatakan memenuhi kriteria untuk pelaksanaan dan layak untuk dilanjutkan dan diujicobakan walau konsep kompensasi non finansialnya berupa kelebihan FAR di Kota Semarang tidak dapat diberikan karena adanya pembatasan dari KKOP. Karena adanya keterbatasan dari sisi ketinggian bangunan yang dapat dilaksanakan di Kota Semarang, maka luasan kawasan pengembangan menjadi salah satu faktor penting agar pengembang dapat melaksanakannya dalam upaya mendapatkan keuntungan. Terkait perijinan, pemerintah Kota Semarang pada dasarnya sudah mulai mengikuti terkait aturan percepatan perijinan dan diharapkan dpat mempermudah pelaksanaan pengembangan. Dari sisi kebijakannya juga hingga saat ini belum dinyatakan perlu untuk dibuatkan aturan khusus pelaksanaannya hanya saja dibutuhkan peningkatan sumberdaya manusianya untuk lebih memahami konsep TDR tersebut mengingat bahwa konsep tersebut merupakan konsep baru yang sedang diupayakan dilaksanakan di Indonesia. Inisiator dari konsep TDR tersebut jika akan dilaksanakan sebaiknya dari pemerintah Kota Semarang sesuai dengan harapan dari masyarakat dan pengembang.

\section{UCAPAN TERIMAKASIH}

Ucapan terima kasih penulis kepada Pusbindiklatren Bappenas yang telah memberikan motivasi dan dukungan anggaran hingga terselesaikannya penelitian ini juga kepada seluruh responden yang menjadi objek penelitian ini seperti Masyarakat Sekayu, Lurah Sekayu, DPD REI Jawa Tengah, Perumnas Regional V Kota Semarang dan Pemerintah Kota Semarang.

\section{REFERENSI}

Aken, J., Eckert, J., Fox, N., \& Swenson, S. (2008). Transfer of Development Rights (TDR) in Washington State: Overview, Benefits, and Challenges. The Cascade Land ..., (March), 1-41. Retrieved from http://dev.forterra.org/files/resources/TDR_in_WA_State_1.pdf

Andini, I. (2013). Sikap dan Peran Pemerintah Surabaya Terhadap Perbaikan Daerah Kumuh Di Kelurahan Tanah Kalikedinding Kota Surabaya. Kebijakan Dan Manajemen Publik, 1(1).

Chan, E. H. W., \& Hou, J. (2014). Developing A framework to Appraise the Critical Success factors of Transfer Development Rights (TDRs) for Built Heritage Conservation. Habitat International.

Chan, E. H. W., \& Hou, J. (2015). Developing a framework to appraise the critical success factors of transfer development rights (TDRs) for built heritage conservation. Habitat International, 46, 35-43. https://doi.org/10.1016/j.habitatint.2014.10.018

Dhabhalabutr, K. (2016). The Empowerment of the Slum Inhabitant as a Primary Agent of Low-Income Housing : Slum Upgrading in Thailand between 1980. Procedia Social and Behavioral Sciences, 216(October 2015), 428-439. https://doi.org/10.1016/j.sbspro.2015.12.057

Evansyah, E., \& Dewi, S. P. (2014). Kebertahanan kampung tua Sekayu terkait keberadaan Mal Paragon di Kota Semarang. Jurnal Ruang, 2(1), 301-310.

Haryanto, A. (2012). Strategi Penanganan Kawasan Kumuh Sebagai Upaya Menciptakan Lingkungan Perumahan Dan Permukiman Yang Sehat (Contoh Kasus: Kota Pangkalpinang). Jurnal PWK Unisba, (4), 11-37.

Haryanto, R., \& Ramdani, B. D. (2013). Preferensi Masyarakat Terhadap Penataan Kawasan Permukiman Nelayan Kumuh Di Desa Kurau, Kecamatan Koba, Kabupaten Bangka Tengah. Jurnal Teknik PWK Volume 2, 2(3), 569-577. Retrieved from http://ejournal-s1.undip.ac.id/index.p\%oAhp/pwk

Janssen-Jansen, L., Spaans, M., \& van der Veen, M. (2008). New instruments in spatial planning: An international perspective on non-financial compensation (Vol. 23). IOS Press.

Janssen-Jansen, L., Spaans, M., \& Veen, M. van der. (2008). New instruments in spatial planning: an international 
Pangaribuan, Haryanto/ Jurnal Pembangunan Wilayah dan Kota, Vol.15, No.2, 2019, 108-121

Doi: https://doi.org/10.14710/pwk.v15i2.21435

perspective on non-financial compensation. IOS Press. Retrieved from http://books.google.com/books?hl=en\&lr=\&id=P-

hiPyhIUYIC\&oi=fnd\&pg=PT1\&dq=New+instruments+in+spatial+planning+An+international+perspective+on+non -financial+compensation\&ots=geDqZIHG52\&sig=EjYD2hVtfWl4fDKHLLLi7-O90JE

Linkous, E. R. (2017). Transfer of development rights and urban land markets. Environment and Planning A, Vol. 49(5). https://doi.org/10.1177/0308518X16686794

Menghini, G., Gemperle, F., Seidl, I., \& Axhausen, K. W. (2015). Results of an Agent-Based market simulation for transferable development rights (TDR) in Switzerland. Environment and Planning B: Planning and Design, 42(1), 157-183. https://doi.org/10.1068/b120066p

Moleong. (2002). Metode penelitian kualitatif. Bandung: Rosda Karya.

Muta'ali, L., \& Nugroho, A. R. (2016). Perkembangan program penanganan permukiman kumuh di Indonesia dari masa ke masa. Gadjah Mada University Press.

Nelson, A. C., Pruetz, R., \& Woodruff, D. (2013). The TDR handbook: Designing and implementing transfer of development rights programs. Island Press.

Pruetz, R., \& Pruetz, E. (2007). Transfer of development rights turns 40. Planning and Environmental Law, 59(6), 3-11. https://doi.org/10.1080/15480755.2007.10394447

Seong-kyu. (2008). Social housing estates and sustainable community development in South Korea. Habitat International, 32, 349-363. https://doi.org/10.1016/j.habitatint.2007.11.005

Souza, F. F. De, Ochi, T., \& Hosono, A. (2018). Land Readjustment: Solving Urban Problems Through Innovative Approach. World Bank Land and Poverty Conference.

Supriatna, A., \& Van Der Molen, P. (2014). Land readjustment for upgrading Indonesian kampung: A proposal. South East Asia Research, 22(3), 379-397. https://doi.org/10.5367/sear.2014.0218

Wilonoyudho, S. (2014). MIGRASI DAN INVOLUSI DI KOTA SEMARANG ( Migration and Involution in Semarang City ). J. MANUSIA DAN LINGKUNGAN, 21(1), 114-120. 